University of Nebraska - Lincoln

DigitalCommons@University of Nebraska - Lincoln

Papers in Plant Pathology

Plant Pathology Department

3-3-2000

\title{
A Potassium Channel Protein Encoded by Chlorella Virus PBCV-1
}

B. Plugge

Albrecht-von-Haller-Institut für Pflanzenwissenschaften, Universität Göttingen, 37073 Göttingen, Germany

S. Gazzarrini

Università degli Studi di Milano, 20133 Milan, Italy

M. Nelson

Megabase Research Products, Lincoln, NE

R. Cerana

DISAT, Università di Milano Bicocca, 20126 Milan, Italy

James L. Van Etten

University of Nebraska-Lincoln, jvanetten1@unl.edu

See next page for additional authors

Follow this and additional works at: https://digitalcommons.unl.edu/plantpathpapers

Part of the Plant Pathology Commons

Plugge, B.; Gazzarrini, S.; Nelson, M.; Cerana, R.; Van Etten, James L.; Derst, C.; DiFrancesco, D.; Moroni, A.; and Thiel, G., "A Potassium Channel Protein Encoded by Chlorella Virus PBCV-1" (2000). Papers in Plant Pathology. 140.

https://digitalcommons.unl.edu/plantpathpapers/140

This Article is brought to you for free and open access by the Plant Pathology Department at DigitalCommons@University of Nebraska - Lincoln. It has been accepted for inclusion in Papers in Plant Pathology by an authorized administrator of DigitalCommons@University of Nebraska - Lincoln. 


\section{Authors}

B. Plugge, S. Gazzarrini, M. Nelson, R. Cerana, James L. Van Etten, C. Derst, D. DiFrancesco, A. Moroni, and G. Thiel

This article is available at DigitalCommons@University of Nebraska - Lincoln: https://digitalcommons.unl.edu/ 
Published in Science 287 (March 3, 2000), pp. 1641-1644; doi 10.1126/science.287.5458.1641 Copyright (c) 2000 by the American Association for the Advancement of Science. Used by permission. http://www.sciencemag.org

Submitted November 3, 1999; accepted January 13, 2000.

\title{
A Potassium Channel Protein Encoded by Chlorella Virus PBCV-1
}

\author{
B. Plugge, ${ }^{1}$ S. Gazzarrini, ${ }^{2}$ M. Nelson, ${ }^{3}$ R. Cerana,${ }^{4}$ J. L. Van Etten, ${ }^{5}$ \\ C. Derst, ${ }^{6}$ D. DiFrancesco, ${ }^{2}$ A. Moroni, ${ }^{2}$ G. Thiel ${ }^{1}$
}

1 Albrecht-von-Haller-Institut für Pflanzenwissenschaften, Universität Göttingen, 37073 Göttingen, Germany. 2 Università degli Studi di Milano, 20133 Milan, Italy.

3 Megabase Research Products, 4711 Huntington Avenue, Lincoln, NE 68604, USA.

4 DISAT, Università di Milano Bicocca, 20126 Milan, Italy.

5 Department of Plant Pathology, University of Nebraska-Lincoln, Lincoln, NE 68583-0722, USA.

6 Institut für Physiologie, Philipps-Universität Marburg, 35033 Marburg, Germany.

The first three authors contributed equally to this work.

Corresponding author - G. Thiel, email gthiel@gwdvms.gwdg.de

Abstract: The large chlorella virus PBCV-1, which contains double-stranded DNA (dsDNA), encodes a 94-codon open reading frame (ORF) that contains a motif resembling the signature sequence of the pore domain of potassium channel proteins. Phylogenetic analyses of the encoded protein, Kcv, indicate a previously unidentified type of potassium channel. The messenger RNA encoded by the ORF leads to functional expression of a potassium-selective conductance in Xenopus laevis oocytes. The channel blockers amantadine and barium, but not cesium, inhibit this conductance, in addition to virus plaque formation. Thus, PBCV-1 encodes the first known viral protein that functions as a potassium-selective channel and is essential in the virus life cycle.

Potassium channels function in eukaryotes and prokaryotes as selective transport proteins for passive $\mathrm{K}^{+}$movement across membranes (1). Common to virtually all known $\mathrm{K}^{+}$channels is a pore domain with eight highly conserved amino acids, TXXTXG(Y/F)G (2, 3). In a functional channel, four subunits surround a pore in which these residues form the selectivity filter (4).

Sequence analysis of the $330-\mathrm{kb}$ dsDNA genome of the plaque-forming chlorella virus PBCV-1 (family Phycodnaviridae) (5) identified a short amino acid sequence in a small ORF (ORF A250R) which resembles the pore domain of $\mathrm{K}^{+}$channel proteins. ORF A250R is predicted to encode a peptide of 94 amino acids (referred to as $\mathrm{Kcv}$ ) with an isoelectric point of 8.7 and a molecular weight of $10.6 \mathrm{kD}$ (Figure 1A). Hydropathy analysis of $\mathrm{Kcv}$ reveals two putative transmembrane domains (Figure 1B) separated by 44 amino acids that contain the $\mathrm{K}^{+}$channel signature sequence TXXTXGFG (Figure 1A, amino acids 60 through 67) (2). The 26 amino acids surrounding this motif display, on average, $61 \%$ similarity and $38 \%$ identity to the pore domains of many $\mathrm{K}^{+}$channel proteins (Figure 1C). Two structurally important aromatic amino acids are also conserved in the $\mathrm{NH}_{2}$-terminal portion of the $\mathrm{KcV}$ pore domain. In the bacterial channel KcsA, two $W$ residues (amino acids 67 and 68 in Figure 1C) are part of a structure that acts as a cuff, keeping the pore open at the appropriate diameter for $\mathrm{K}^{+}$passage (6). In Kcv as well as in several other $\mathrm{K}^{+}$channel proteins, aromatic $\mathrm{Y}$ or $\mathrm{F}$ residues replace these residues (Figure 1C).

In contrast to the putative pore domain, the amino acid sequences of the two $\mathrm{Kcv}$ transmembrane domains differ markedly from other $\mathrm{K}^{+}$channels. A phylogenetic comparison with eukaryotic Kir, $\mathrm{Kv}$, and tandem $\mathrm{K}^{+}$channels,
A

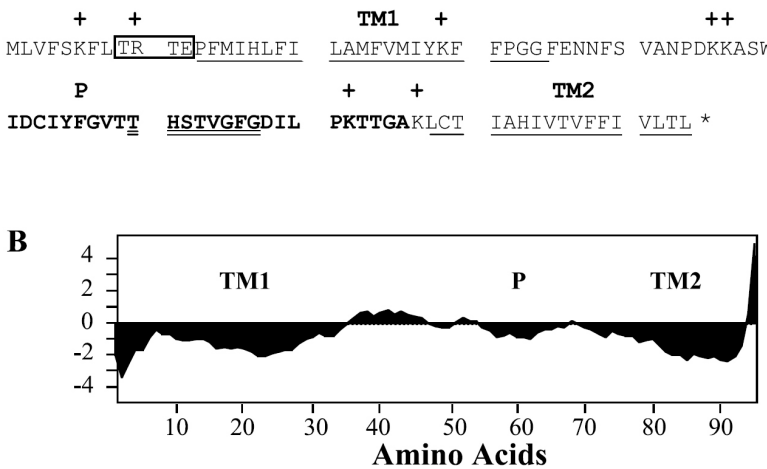

Figure 1. (A) Predicted amino acid sequence of chlorella virus PBCV$1 \mathrm{Kcv}$ protein (GenBank accession AAC96618). Transmembrane regions ( TM1, TM2) are underlined; pore region ( $P$ ) is boldface; $\mathrm{K}^{+}$ channel signature sequence is double underlined; positively charged amino acids are marked by (+); a putative phosphorylation site ( TRTE) is boxed. (B) Hydrophobicity profile (ordinate) was calculated according to Kyte and Doolittle (24) with a moving window of 19 amino acids and plotted against amino acid number (abscissa). (C) Alignment of the Kcv P domain with other $\mathrm{K}^{+}$channel proteins (25). Amino acids similar or identical to Kcv are boldface. Following each sequence, the position of the last residue and the percent amino acid similarity and identity to Kcv (in brackets) are indicated. (D) Phylogenetic comparison of $\mathrm{Kcv}$ with eukaryotic and prokaryotic (denoted by asterisk) $\mathrm{K}^{+}$ channels calculated by CLUSTAL/CLUSTREE algorithms (26).

\section{C}

\begin{tabular}{|c|c|c|c|c|c|}
\hline & & & & & $\% \operatorname{sim}$ (id) \\
\hline Kev1 & IDCIYFGVTT & HSTVGFGDIL & PKTTGA & 76 & \\
\hline Tandem-K & 1st pore & & & & \\
\hline $\mathrm{k} 1 / 1$ & GNALYFCTVS & LLTVGLGDIL & PKSVGA & 155 & $65(50)$ \\
\hline trek $1 / 1$ & GSSFFFAGTV & ITTIGFGNIS & PRTEGG & 155 & $65(39)$ \\
\hline Tandem-K & 2nd pore & & & & \\
\hline $\mathrm{C} 24 \mathrm{~A} 3 / 2$ & GTSLYFTLIS & FTTIGFGDIL & PSDYDF & 279 & $58(39)$ \\
\hline $\mathrm{T} 12 \mathrm{C} 9 / 2$ & MDAFYYSF $\perp \mathbf{S}$ & LTTIGFGDIV & PENHDY & 496 & $62(35)$ \\
\hline $\begin{array}{l}\text { PAK family } \\
\text { pak1 }\end{array}$ & LHSLYWSIIT & MTTIGYGDIT & PQNLRE & 354 & $58(31)$ \\
\hline pak2 & FNSLYWITIT & SMTVGYGDIV & PVTTPE & 340 & $62(42)$ \\
\hline EAG family & & & & & \\
\hline 8 & VTALYFTMTC & MTSVGFGNVA & AETDNE & 466 & $50(31)$ \\
\hline herg & VTALYFTFSS & LTSVGFGNVS & PNTNSE & 637 & $62(31)$ \\
\hline okaryo & channel genes & & & & \\
\hline $\mathrm{A}$ & PRALWWSVET & ATTVGYGDLY & PVTLWG & 88 & $62(35)$ \\
\hline $\mathrm{Kch}$ & MTAFYFSIET & MSTVGYGDIV & PVSESA & 198 & $65(46)$ \\
\hline & & & & & $61(38)$ \\
\hline
\end{tabular}

D

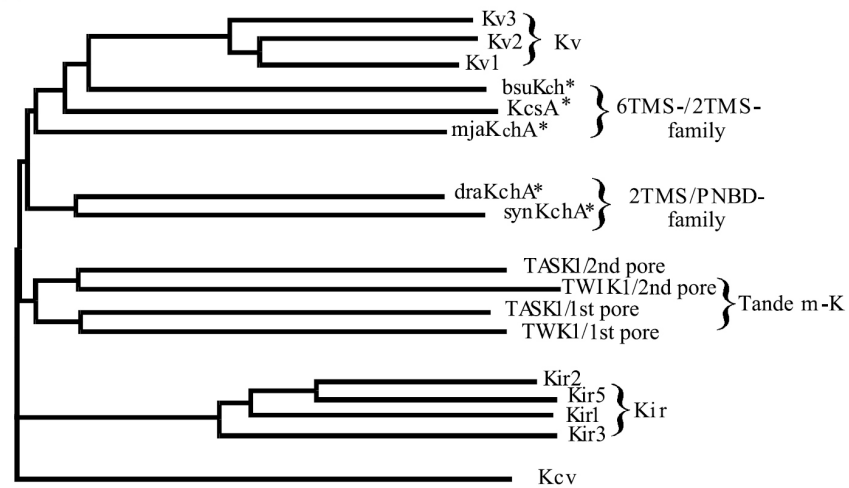


and two prokaryotic $\mathrm{K}^{+}$channel families (7), places Kcv as an independent cluster, indicating significant sequence deviation (Figure 1D). Another unusual feature of Kcv is its short (12 amino acids) cytoplasmic $\mathrm{NH}_{2}$-terminus containing a consensus protein kinase ck2 phosphorylation site (Figure 1A, amino acids 9 through 12). The $\mathrm{COOH}$-terminus of the $\mathrm{Kcv}$ protein is part of the second transmembrane region; $\mathrm{Kcv}$ thus appears to lack a $\mathrm{COOH}$-terminal cytoplasmic tail. These structural data and the phylogenetic analysis suggest that $\mathrm{Kcv}$ represents a very primitive $\mathrm{K}^{+}$channel. This notion is supported by phylogenetic analyses of another viral protein that place the DNA polymerases from Phycodnaviridae near the root of all eukaryotic DNA polymerase delta proteins (5). This indicates that at least some PBCV-1-encoded proteins have long evolutionary histories.

To determine if $\mathrm{Kcv}$ functions as an ion channel, we expressed the protein in Xenopus oocytes (8). At 36 hours after Kcv mRNA injection, oocytes exhibited

A

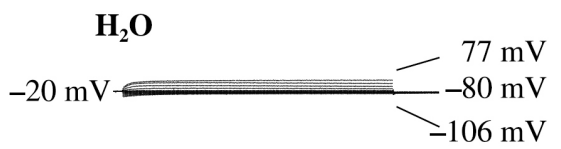

Kev mRNA

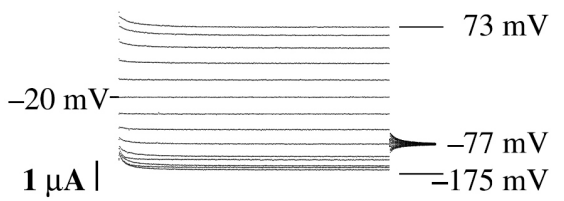

$10 \overline{\mathrm{ms}}$

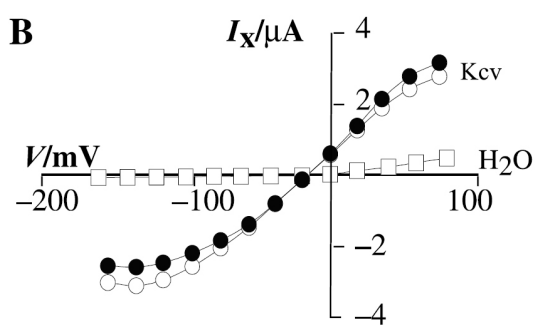

Figure 2. Heterologous expression of the PBCV-1 encoded $\mathrm{K}^{+}$channel homolog $\mathrm{Kcv}$ in Xenopus oocytes. (A) Currents recorded in 50 $\mathrm{mM} \mathrm{KCl}$ from oocytes injected with water or Kcv mRNA were induced by voltage steps from holding voltage to test voltages as indicated. (B) $I_{\mathrm{i}}$ (solid symbols) and $I_{\mathrm{ss}}$ (open symbols) as a function of applied test voltages. Currents were measured after $3 \mathrm{~ms}\left(I_{\mathrm{i}}\right)$ and at the end of the test pulse $\left(I_{\mathrm{ss}}\right)$. (C) $I_{\mathrm{f}} / \mathrm{V}$ relations from a $\mathrm{Kcv}$ mRNA-injected oocyte in 2,20 , and $50 \mathrm{mM} \mathrm{KCl}$ measured as in (B). (D) Deactivation tail currents from a Kcv mRNA-injected oocyte in $50 \mathrm{mM} \mathrm{KCl}$. Currents were elicited by clamping the oocyte to $-160 \mathrm{mV}$ for $1 \mathrm{~s}$ to activate time-dependent conductance. To follow current relaxation, voltage steps were applied in the ranges indicated. $(E)$ Reversal voltages $\left(V_{r}\right)$ obtained from $I_{i} / V$ relations (solid symbols, $n=9$ oocytes) and tail currents (open symbols, $n=8$ oocytes) in Nernst plot against extracellular $\mathrm{K}^{+}$concentration. Linear regression to mean $V_{\mathrm{r}}$ from both types of analysis has a slope of $60.0 \mathrm{mV} /$ decade.

distinct currents in voltage clamp assays (9) which differed quantitatively and qualitatively from control oocytes (Figure 2, A and B) (10). At voltages of +60 and $-140 \mathrm{mV}$, average steady-state currents of Kcv mRNA-injected oocytes exceeded those of water-injected ones by factors of 8.6 and 8.2, respectively (11). The conductance introduced by $\mathrm{Kcv}$ mRNA injection consisted of an instantaneous and a time-dependent component (Figure 2A). The instantaneous $I / V$ relation deviated from linearity by decreasing at extreme hyperpolarizing and depolarizing voltages. The time-dependent current activated and deactivated at negative and positive voltages, respectively. Figure $2 \mathrm{~B}$ shows the instantaneous $\left(I_{\mathrm{i}}\right)$ and steady state-current $\left(I_{\mathrm{ss}}\right)$ from $\mathrm{KcV}$ mRNA-injected oocytes and the steadystate component of water-injected oocytes as a function of voltage.

The selectivity of Kcv-mediated conductance was determined by obtaining $I_{\mathrm{i}} / V$ relationships at 2, 20, and $50 \mathrm{mM}$ $\mathrm{KCl}$ (Figure 2C). Lowering the external
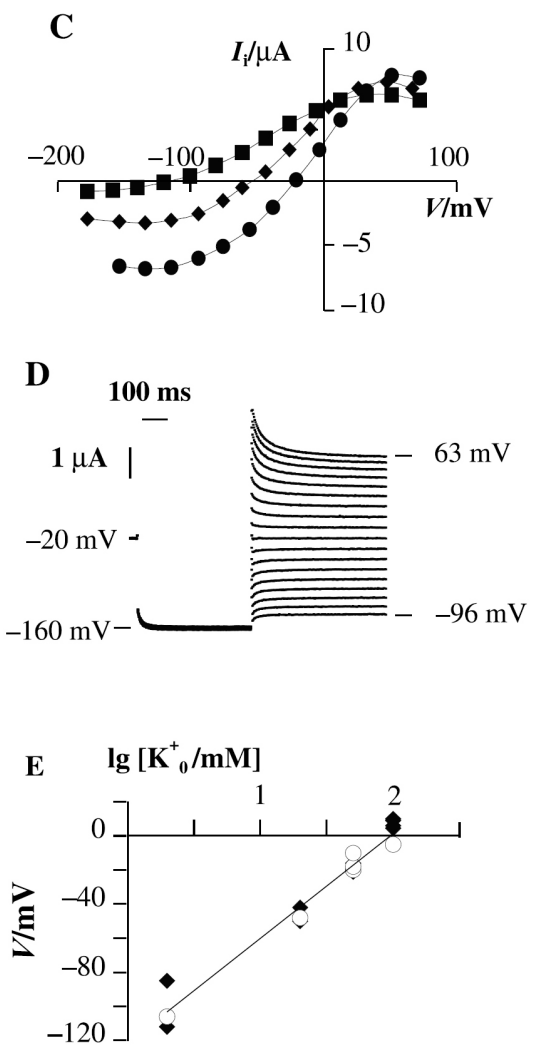

oth types of analysis has a slope of $60.0 \mathrm{mV} / \mathrm{decade.}$
$\mathrm{K}^{+}$concentration $\left(\mathrm{K}_{0}^{+}\right)$caused the current reversal voltage $\left(V_{\mathrm{r}}\right)$ to shift to more negative voltages and the inward current to decrease. Plotting $V_{\mathrm{r}}$ versus $\mathrm{K}_{0}^{+}$in a Nernst plot yielded a slope of $60.0 \mathrm{mV}$ per decade (Figure 2E). Figure 2D shows the time-dependent deactivation of the current following activation at a conditioning voltage of $-160 \mathrm{mV}$. The current reversed at $-20 \mathrm{mV}$, a value close to the reversal of $I_{i}$. This result was confirmed at all $\mathrm{K}_{0}^{+}$values investigated (Figure $2 \mathrm{E}$ ). Taken together, these analyses show that $\mathrm{Kcv}$ is a channel that conducts $\mathrm{K}^{+}$ions.

The cation selectivity of Kcv-mediated conductance was examined by replacing $\mathrm{KCl}$ with $\mathrm{NaCl}$ in the bath solution. Both the time-dependent and instantaneous currents were strongly depressed (Figure 3). Furthermore, $V_{\mathrm{r}}$ shifted negative by $68 \mathrm{mV}$, indicating that the Kcv-mediated conductance prefers $\mathrm{K}^{+}$over $\mathrm{Na}^{+}$ ions. The $P_{\mathrm{K}} / P_{\mathrm{Na}}$ permeability ratio from $n=10 \mathrm{I} / \mathrm{V}$ relations was 9.32 (12). Current reduction at positive voltages suggests an inhibitory effect of $\mathrm{Na}^{+}$on the $\mathrm{K}^{+}$outward current.

These results indicate that $\mathrm{Kcv}$ forms a $\mathrm{K}^{+}$-selective channel in oocytes (13). $\mathrm{KcV}$ is the smallest $\mathrm{K}^{+}$channel protein known, primarily because of its short $\mathrm{NH}_{2}$ - and $\mathrm{COOH}$-termini. The $\mathrm{NH} 2-$ and $\mathrm{COOH}$-terminal domains of other $\mathrm{K}^{+}$

\section{A}
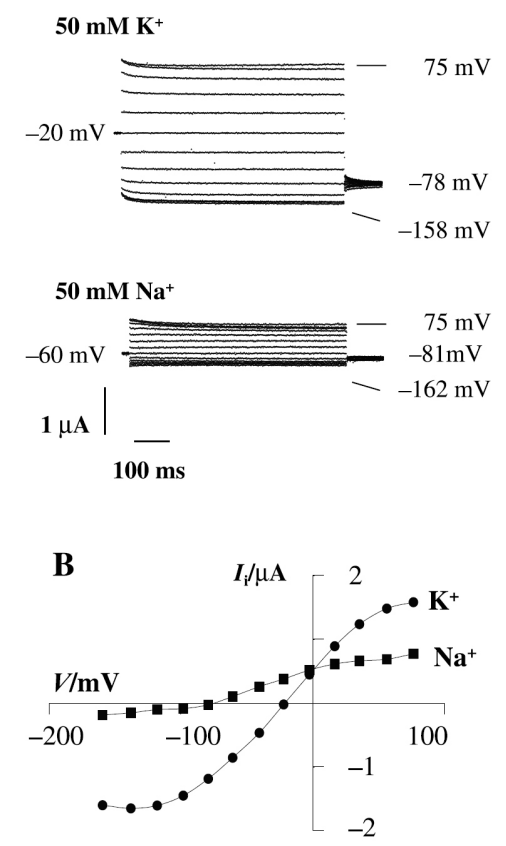

Figure 3. Selectivity of the Kcv-mediated conductance. Currents were elicited in response to voltage steps from resting voltage to test voltages in the ranges indicated. The bath solution in (A) contained $50 \mathrm{mM} \mathrm{KCl}$ or $50 \mathrm{mM}$ $\mathrm{NaCl}$. (B) $I_{\mathrm{i}} / \mathrm{V}$ relation of data in (A). 
channel proteins contribute to pore assembly and voltage sensitivity (14). Despite lacking these domains, Kcv displays several distinct properties with moderate voltage-sensitivity including (i) a decrease in $I_{\mathrm{i}}$ near both voltage extremes, (ii) a hyperpolarization-induced time-dependent activation, and (iii) a depolarization-induced time-dependent decrease of the conductance (Figure 2, A and B).

Oocytes expressing Kcv were exposed to amantadine, an antiviral drug which at concentrations $<1 \mu \mathrm{M}$ inhibits the influenza virus M2 protein (15). Amantadine inhibited the Kcv-mediated conductance (Figure 4A). Inhibition of $I_{\mathrm{i}}$ was voltageindependent (Figure 4A, lower panel). To quantify inhibition, we measured the effect of amantadine on the physiologically relevant steady-state current: At +60 and $-140 \mathrm{mV}, I_{\mathrm{ss}}$ was half-inhibited by 2 and $0.8 \mathrm{mM}$ amantadine, respectively (16). Thus, the effective concentration is about three orders of magnitude higher than required to inhibit M2. Amantadine inhibition of Kcv-mediated conductance reversed within minutes after removal of

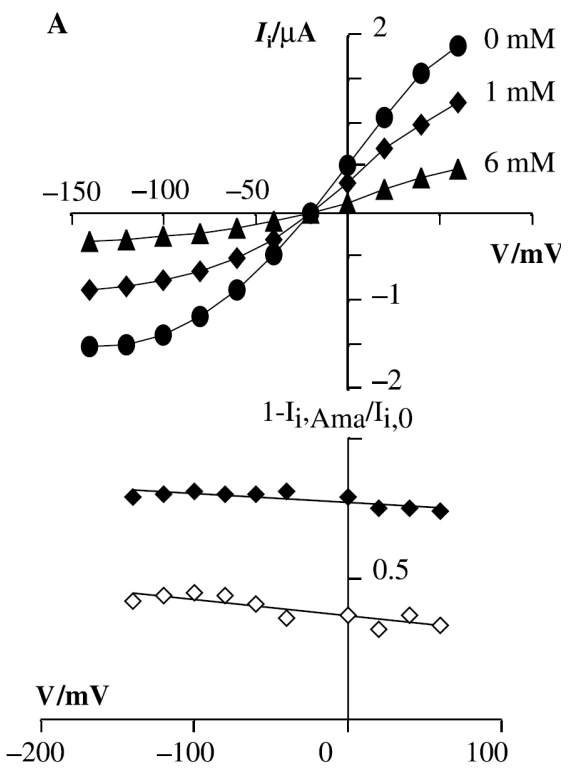

Figure 4. Inhibition of Kcv-mediated conductance and virus replication by $\mathrm{K}^{+}$channel blockers. [(A), upper panel] $I_{i} / V$ in Kcv mRNAinjected oocytes with addition of $0(\bullet), 1(\bullet)$, and $6(\boldsymbol{\Delta}) \mathrm{mM}$ amantadine to the bath solution. [(A), lower panel] Relative block (1 $\left.I_{\mathrm{i}, \mathrm{Ama}} / I_{\mathrm{i}, 0}\right)$ from data in upper panel as a function of voltage (amantadine: $\diamond 1 \mathrm{mM}, 6$ $\mathrm{mM})$. [(B), upper panel] $I_{\mathrm{i}} / V$ relations in $\mathrm{Kcv}$ mRNA-injected oocytes before $(\bullet)$ and after (घ) adding $1 \mathrm{mM} \mathrm{BaCl} 2$ to the bath solution.

[(B), lower panel] Relative block $\left(1-I_{\mathrm{i}, \mathrm{Ba}} / I_{\mathrm{i}, 0}\right)$ from data in the upper panel as function of voltage. Data fitted (solid line) with Woodhull block model (18), yielding $b_{\max }=0.93, \delta=0.91$, and $k^{0}=$ $650 \mu \mathrm{M}\left(n=3\right.$ oocytes). (C) Relative inhibition $\left(1-A / A_{0}\right)$ of virus plaque formation $(\diamond)$ and Kcvmediated $I_{\text {ss }}$ at $+60 \mathrm{mV}(\bullet)$ and $-140 \mathrm{mV}(\boldsymbol{\Delta})$ as function of amantadine concentration in the external medium. Mean of four experiments; $\mathrm{SE}$ is smaller than symbols. the drug. In contrast, amantadine inhibition of M2 is essentially irreversible (15). These results, together with the fact that the two viral-encoded proteins have little or no structural similarity, suggest that amantadine inhibits the Kcv and M2 proteins by different mechanisms (17).

Kcv-mediated conductance was also exposed to the typical $\mathrm{K}^{+}$channel blockers $\mathrm{Cs}^{+}$and $\mathrm{Ba}^{2+}$. Addition of $10 \mathrm{mM}$ $\mathrm{CsCl}$ had only modest effects on the Kcvmediated conductance. The inward current at $-140 \mathrm{mV}$ was inhibited by $9 \pm 4 \%$, whereas the outward current at $+60 \mathrm{mV}$ was unaffected ( $n=4$ oocytes). In contrast, $\mathrm{Ba}^{2+}$ reduced the $\mathrm{Kcv}$-mediated conductance in a voltage-dependent manner (Figure 4B) (18). This behavior supports the hypothesis that $\mathrm{Ba}^{2+}$ blocks inward current in $\mathrm{K}^{+}$channels after being drawn into the pore by negative voltage (19).

A plaque reduction assay (20) was employed to determine the importance of Kcv to virus replication (21). Amantadine inhibited PBCV-1 plaque formation by $50 \%$ at $2.8 \pm 0.2 \mathrm{mM}(n=4)(16)$, that
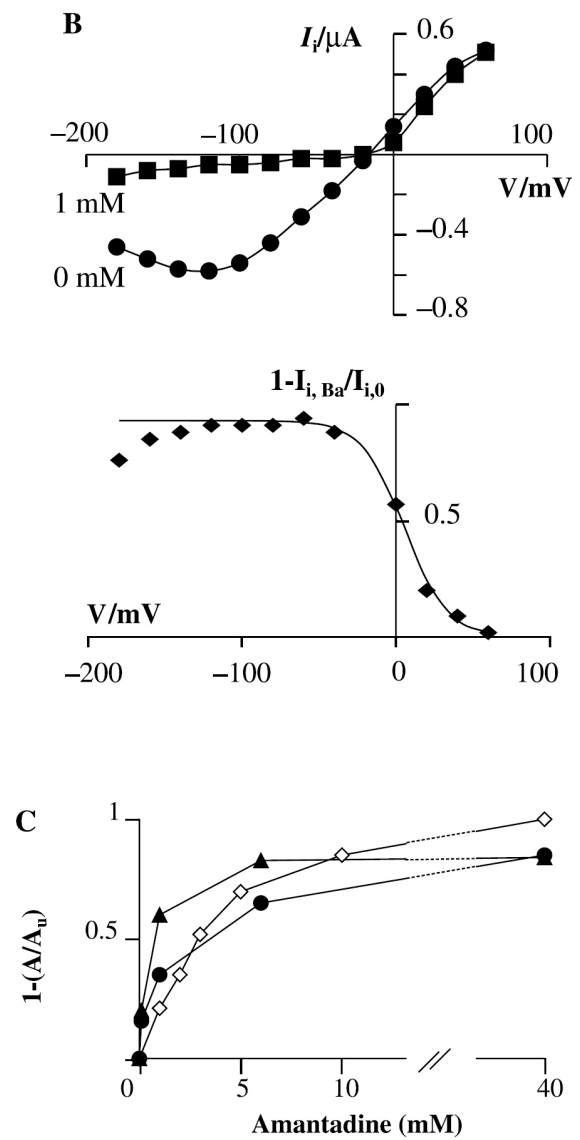

is, at approximately the same millimolar concentration that affected the Kcv-mediated conductance (Figure 4C). Plaque formation was also inhibited $50 \%$ by 2.6 $\pm 0.16 \mathrm{mM} \mathrm{Ba}^{2+}(n=3)$, a concentration sufficient to abolish Kcv inward current. Cesium $(10 \mathrm{mM})$ had no apparent effect on PBCV-1 replication. These results, together with the finding that the Kcv gene is expressed early after virus infection (22) indicate that PBCV-1 replication depends, in a yet unknown manner, on a functional Kcv channel.

In conclusion, chlorella virus PBCV-1 encodes a functional $\mathrm{K}^{+}$channel protein, $\mathrm{KcV}$, which is important for virus replication. Prior to this study, only four virusencoded proteins were thought to have ion channel activities: influenza virus A M2 protein, influenza virus B NB protein, and the human immunodeficiency virus proteins Vpu and Vpr (23). PBCV-1 is the first virus known to encode a $\mathrm{K}^{+}$-selective channel. Because of its exceptionally small size, Kcv may become a useful tool to study basic principles of channel assembly and function.

\section{References and Notes}

1. L. Y. Jan and Y. N. Jan, Annu. Rev. Neurosci. 20, 91 (1997).

2. L. Heginbotham, Z. Lu, T. Abramson, R. MacKinnon, Biophys. J. 66, 1061 (1994).

3. Single-letter abbreviations for the amino acid residues are as follows: A, Ala; C, Cys; D, Asp; E, Glu; F, Phe; G, Gly; H, His; I, Ile; K, Lys; L, Leu; M, Met; N, Asn; P, Pro; Q, GIn; R, Arg; S, Ser; T, Thr; V, Val; W, Trp; and $Y$, Tyr. $X$ indicates any residue.

4. R. MacKinnon, Nature 350, 232 (1991).

5. J. L. Van Etten and R. H. Meints, Annu. Rev. Microbiol. 53, 447 (1999).

6. D. A. Doyle et al., Science 280, 69 (1998).

7. C. Derst and A. Karschin, J. Exp. Biol. 201, 2791 (1998).

8. ORF A250R was amplified from PBCV-1 genomic DNA by polymerase chain reaction, using primers with restriction sites for Bam HI ( $5^{\prime}$ end) and Xho I ( $3^{\prime}$ end). The amplified fragment was cut with the two enzymes and ligated into predigested vector pSGEM (constructed from pGEM-HE, given to B. Plugge by courtesy of M. Hollmann, Max-Planck-Institut for Experimental Medicine, Göttingen, Germany). The cDNA templates were linearized with Nsi I and transcribed in vitro with T7 RNA polymerase. The mRNA was injected in Xenopus laevis oocytes. Membrane currents and voltages were recorded with conventional twoelectrode voltage clamp method, using the Gene Clamp 500 amplifier under control of pCLAMP 5.5 software. Both electrodes were filled with $3 \mathrm{M} \mathrm{KCl}$ and had resistances between 0.4 and 1 megohms in 50 $\mathrm{mM} \mathrm{KCl}$. The oocytes were continually perfused $\left(25^{\circ} \mathrm{C}\right)$ with experimental solution 
(about $2 \mathrm{ml} \mathrm{min}^{-1}$ ) containing $50 \mathrm{mM} \mathrm{KCl}$, $1.8 \mathrm{mM} \mathrm{CaCl}_{2}, 1 \mathrm{mM} \mathrm{MgCl}_{2}$, and $5 \mathrm{mM}$ Hepes/LiOH ( $\mathrm{pH}$ 7.4). Mannitol was used to adjust the osmolarity to $215 \mathrm{mOsmol}$.

9. The amount of mRNA injected was limited to $1 \mathrm{ng} / 50 \mathrm{nl}$. Injection of higher amounts of mRNA or expression times longer than 48 hours caused oocytes to die.

10. Two typical dominant endogenous currents were recorded in $\mathrm{H}_{2} \mathrm{O}$-injected oocytes: (i) an inactivating inward rectifying $\mathrm{K}^{+}$current and (ii) a time-dependent outward rectifying $\mathrm{Cl}^{-}$current [C. K. T. Bauer, J. R. Falk, W. Schwarz, Pfluegers Arch. 432, 812 (1996); N. Dascal, Crit. Rev. Biochem. 22, 317 (1987)].

11. Steady-state currents at test voltage of $+60 \mathrm{mV}$ and $-140 \mathrm{mV}$ (voltage protocols as in Figure 2) recorded in oocytes injected with (i) $\mathrm{H}_{2} \mathrm{O}:+0.2 \pm 0.05 \mu \mathrm{A}$ and $-0.22 \pm$ $0.08 \mu \mathrm{A}(n=9)$; (ii) Kcv mRNA: $+1.63 \pm$ $0.37 \mu \mathrm{A}$ and $-1.89 \pm 0.44 \mu \mathrm{A}(n=17)$.

12. The $P_{K} / P_{\mathrm{Na}}$ permeability ratio was calculated by least-squares fitting of reversal potentials in either external $\mathrm{KCl}$ or $\mathrm{NaCl}$ solutions by the GHK equation [B. Hille, Ionic Channels of Excitable Membranes (Sinauer, Sunderland, MA, 1992)], assuming permeation of $\mathrm{K}^{+}$and $\mathrm{Na}^{+}$ions only. Oocyte intracellular $\mathrm{Na}^{+}$and $\mathrm{K}^{+}$concentrations were assumed to be $20 \mathrm{mM}$ [K. Kusano, R. Miledi, J. Stinnakre, J. Physiol (London) 328, 143 (1982)] and 101 mM (based on the fitting of the Nernst plot in Figure 2E), respectively.

13. However, the possibility exists that $\mathrm{Kcv}$ functions as a subunit, which up-regulates the activity of endogenous $\mathrm{K}^{+}$channels in oocytes. To exclude this possibility, we constructed a site-specific mutation in the selectivity filter sequence of $\mathrm{Kcv}$ by replacing Phe ${ }^{66}$ (F66) with Ala (A). If Kcv is a channel protein, the mutant protein should, by analogy to the Shaker channel, form a channel unable to conduct $\mathrm{K}^{+}$cur- rents (1). Using standard voltage-clamp assays, nine oocytes expressing KcvF66A had currents similar in kinetics to those of $\mathrm{H}_{2} \mathrm{O}$-injected oocytes with no additional $\mathrm{K}^{+}$conductance compared to the $\mathrm{H}_{2} \mathrm{O}$-injected control cells. Hence, the absence of a prominent $\mathrm{K}^{+}$-selective current in KcvF66A-expressing oocytes confirms that $\mathrm{Kcv}$ functions as a channel protein in oocytes and that the observed currents are not due to activation of endogenous channel proteins.

14. G. Yellen, Curr. Opin. Neurobiol. 9, 267 (1999); D. M. Papazian, Neuron 23, 7 (1999).

15. C. Wang, K. Takeuchi, L. H. Pinto, R. A. Lamb, J. Virol. 67, 5585 (1993).

16. Concentration for half-maximal inhibition estimated by fitting Michaelis-Menten type kinetics to data.

17. The adamantyl group of amantadine is believed to interact with the hydrophobic lining of the M2 pore, whereas the ammonium group forms $\mathrm{H}$ bonds with the imidazole ring of $\mathrm{His}^{37}$ [C. S. Gandhi et al., J. Biol. Chem. 274, 5474 (1999)].

18. Voltage-dependency of inhibition by $\mathrm{Ba}^{2+}$ was analyzed quantitatively based on a Woodhull block model [A. M. Woodhull, J. Gen. Physiol. 61, 687 (1973)] by fitting data of relative block to

$$
\left(1-I / I_{0}\right)=b_{\max } /\left[1+\left(k^{0} / B_{a}\right) e^{(z \delta F / R T)}\right]
$$
where $I_{0}$ is control and $I$ blocked current, $b_{\max }$ the maximal block, $B_{a}$ the concentration of $\mathrm{Ba}^{2+}, k^{0}$ the dissociation constant of the blocking reaction at voltage $=0 \mathrm{mV}$, $\delta$ the fraction of the electrical field crossed by $\mathrm{Ba}^{2+}$, and $z=2$ the valence of the blocking ion. $R, T$, and $F$ have their usual thermodynamic meaning. Fitting yields for $1 \mathrm{mM} \mathrm{Ba}^{2+}: b_{\max }=0.94, \delta=0.9 \pm 0.03$, and $k^{0}=660 \pm 12 \mu \mathrm{M}$ ( $n=3$ oocytes).

19. R. Z. Sabirov, T. Tominaga, A. Miwa, Y. Okada, S. Oiki, J. Gen. Physiol. 110, 665
(1997); R. C. Shieh, J. C. Chang, J. Arreola, Biophys. J. 75, 2313 (1998); J. M. Owen, C. C. Quinn, R. Leach, J. B. Findlay, M. R. Boyett, Exp. Physiol. 84, 471 (1999).

20. J. L. Van Etten, D. E. Burbank, Y. Xia, R. H. Meints, Virology 126, 117 (1983).

21. About 1200 plaque-forming units of virus PBCV-1, or a small plaque variant $\mathrm{P} 1210$ [D. Landstein, D. E. Burbank, J. W. Nietfeldt, J. L. Van Etten, Virology 214, 413 (1995)], were mixed with $10^{8}$ host cells (Chlorella strain NC64A) and warm MBBM top agar containing various concentrations of ion-channel inhibitors. The mixture was layered onto MBBM nutrient agar (22). After incubating for 2 days at $25^{\circ} \mathrm{C}$, viral plaques were counted. Potassium concentration of MBBM growth medium was 1.3 $\mathrm{mM}$.

22. J. L. Van Etten, unpublished results.

23. R. A. Lamb and L. H. Pinto, Virology 229 , 1 (1997).

24. J. Kyte and R. F. Doolittle, J. Mol. Biol. 157, 105 (1982).

25. Channel nomenclature according to (7) and A. Wei, T. Jegla, L. Salkoff, Neuropharmacology 35, 805 (1996).

26. J. D. Thompson, D. G. Higgins, T. J. Gibson, Nucleic Acids Res. 22, 4673 (1994); N. Saitou and M. Nei, Mol. Biol. Evol. 4, 406 (1987). Only the pore region and flanking transmembrane segments were used for the phylogenetic comparisons. For Kir and $\mathrm{Kv}$ channels, consensus sequences of the appropriate subfamily were used in the calculations.

27. We thank H. Terlau, D. Gradmann, and M. Blatt for helpful discussions. Supported in part by MURST in the framework of Cofin-99, NIH grant GM32441 to J.V.E. Small Business Innovative Research grant GM41333 to M.N., Telethon grants (\#971 and \#296.bi) to D.D. and A.M., and a traveling grant by the SmithKline Beecham foundation to B.P. 